It will be recalled that the International Court of Justice in the Corfu Channel case rejected the defense of the United Kingdom that it had used armed force in the cause of international justice. The Court's pronouncement on this bears repetition:

The Court cannot accept such a line of defence. The Court can only regard the alleged right of intervention as the manifestation of a policy of force, such as has, in the past, given rise to most serious abuses and such as cannot, whatever be the present defects in international organization, find a place in international law. Intervention is perhaps still less admissible in the particular form it would take here; for, from the nature of things, it would be reserved for the most powerful States, and might easily lead to perverting the administration of international justice itself. ${ }^{9}$

The Court's measured phrases remind us of the historic realities of abuse by powerful states for supposedly good causes. It is no answer to say that invasions should be allowed where there is no abuse and only for the higher good of selfdetermination. In the absence of an effective international mechanism to restrain force, individual governments would have wide latitude to decide on the "reality" of democracy and self-determination in various countries. The test one side would favor would not be acceptable to others. Ideological confrontations would sooner or later become clashes of power.

These considerations are so evident that we can be quite sure that governments will not adopt the suggested reinterpretation of Article 2(4) as law. Not even its espousal by a powerful state would make it law. In short, it is not, will not and should not be law. Yet there is reason for concern that the thesis has been put forward by an international lawyer of standing. In this period of tension and unilateral action, arguments such as those presented may influence policy in favor of armed intervention. The fragility of international organization enhances the danger. This is surely not the time for international lawyers to weaken the principal normative restraint against the use of force. The world will not be made safe for democracy through new wars or invasions of the weak by the strong.

OSCAR SCHACHTER

\title{
REPORTING THE FACTS AS THEy ARE NOT KNOWN: MEDIA RESPONSIBILITY IN CONCEALED HUMAN Rights Violations
}

All I know is just what I read in the papers.
Will Rogers

When formal institutions prove unable to discharge indispensable social tasks, functional equivalents develop. Consider the institutional fact-gathering pro-

${ }^{9}$ Corfu Channel case, 1949 ICJ REP. 4, 35 (Judgment of Apr. 9). 
cedures of the international legal system. Because they are underdeveloped or ineffective, authoritative decision makers must depend, to an astonishing degree, on the private media for the images that lead to provisional characterizations of norm violation and the initiation of international action. Even where the intelligence and invocation functions of decision are institutionally developed and effective in high degree, independent and vigorous media are not redundant. Their presence and activity supplement and police official fact-gathering procedures. In the United States, media frequently initiate decision by provisionally characterizing certain behavior as improper. This latent role of private national media is even more urgent internationally.

In the latter part of the 20th century, the United States has become a routine global actor and decision maker in an increasingly interdependent world. The American public, which is often a factor in stimulating governmental action, is almost wholly dependent on the media, for the greater part of the artifact we call social and political reality is media reality, produced by the contemporary media. Because public conceptions of the reality "out there" acquire decisive importance for the quality and accuracy of decision making, the latent responsibilities of the media in international decision are great.

Structurally, American media are amply endowed to perform this function, for they are composed of large organizations of disciplined and skilled persons operating globally and in a state of electronic simultaneity. Yet, paradoxically, some of the in-house norms that have contributed to the effectiveness of American journalism may undermine new global responsibilities.

American journalism developed its organization, discipline and ethics in a domestic setting. Its basic equation was the right to inquire and publish, balanced by an obligation to conduct inquiry responsibly. The norm deemed most appropriate in that setting was that one reported only "facts," i.e., events that could be verified through the specialized procedures of the journalist.

The "fact test" contributed to a better product not only because journalists were aggressive and accurate but because the events in question were generally available to inquiry. An equilibrium of political forces produced a national political and social ethics committed to protecting vigorous investigation by journalists. If a government or private agency sought to impede that process, a supervening norm, frequently misleadingly called the "right to know," could be invoked. Despite the fact that publication might injure some of the individuals reported on, constitutional doctrine provided a broad immunity for journalists, which was kept within responsible bounds by the self-policing norm of the "facts test."

The norm developed for domestic settings often produces skewed results when it is applied in materially different foreign contexts. Ironically, the more closed a regime and the more systematic and efficient it is in the suppression of information about its activities, the cleaner it is likely to be in the reality conception produced by United States media. Conversely, the more open an authoritarian regime, the blacker the picture U.S. media will paint of it.

Consider North and South Korea. ${ }^{1}$ Both are authoritarian, repressive regimes, though there are great variations in degree between them. Both have political

\footnotetext{
'I am grateful to Richard Bernstein for this example.
} 
prisoners. Due to the comparative openness of South Korea, American journalists may speak to former prisoners, their families and their lawyers and they may benefit from opposition parties and groups that invest time in collecting pertinent information. Owing to the availability and verifiability of this information (a function of the political system in which it occurs), it meets the fact norm of American journalism and can be reported to the United States public. The resulting picture of South Korea is reasonably accurate. North Korea, in contrast, is completely closed. Even if a journalist can enter, he or she is unlikely to be able to speak to prisoners or former prisoners, for their families, if accessible, may be too fearful to speak.

There are practical political and especially human rights consequences because of the nexus between media reality and political action. The fact test American journalism employs produces a spate of articles detailing repression in South Korea but almost no such articles on North Korea. Diachronic comparisons may produce comparable asymmetries. Contemporary Vietnam will appear less repressive than the defunct Republic of Vietnam. The Islamic Republic will appear less repressive than Pahlavi Iran. Reality may be quite different from these media images. The discrepancies are amplified politically, for public images of reality and consequent demands on decision makers are largely shaped by what the media present as happening in authoritarian states.

There are ethical as well as public policy reasons for American journalism to consider the dysfunction caused when a journalistic norm designed for domestic purposes is applied to radically different foreign contexts. The simplest remedy would be to adopt several probative techniques of the law: burden of proof, presumption and the best evidence rule. Journalists would shift the burden of proof onto any government that systematically prevents scrutiny by the free media of events incompatible with basic human rights norms as expressed in the fundamental human rights instruments of international law. When reports of human rights violations by a closed government begin to accumulate and the reports are credible, multiple or consistent with previous behavior, journalists should assume that a prima facie case has been established against that government. The burden of proof sufficient to overcome this presumption shifts to the government that is itself barring scrutiny by the media. If it is willing to open up its borders and permit the international media to examine the allegations, reporting should be withheld until determinations, using ordinary journalistic methods, can be made. But if the regime resists, the media should presume that the government in question has good reasons for concealment. The suspicion of atrocities should be reported.

\section{W. MICHAEL REISMAN*}

\footnotetext{
* This Editorial Comment was submitted to the Journal while the author was a member of the Board of Editors.
} 